\title{
European Union legislation on macroalgae products
}

\author{
Anu Lähteenmäki-Uutela ${ }^{1}$ (D) - Moona Rahikainen ${ }^{2} \cdot$ María Teresa Camarena-Gómez $^{3}$. \\ Jonna Piiparinen ${ }^{3} \cdot$ Kristian Spilling $^{3,4}$ - Baoru Yang ${ }^{2}$
}

Received: 5 September 2020 / Accepted: 9 December 2020 / Published online: 20 January 2021

(C) The Author(s) 2021

\begin{abstract}
Macroalgae-based products are increasing in demand also in Europe. In the European Union, each category of macroalgae-based products is regulated separately. We discuss EU legislation, including the law on medicinal products, foods including food supplements and food additives, feed and feed additives, cosmetics, packaging materials, fertilizers and biostimulants, as well as biofuels. Product safety and consumer protection are the priorities with any new products. Macroalgae products can be sold as traditional herbal medicines. The novel food regulation applies to macroalgae foods that have not previously been used as food, and organic macroalgae are a specific regulatory category. The maximum levels of heavy metals may be a barrier for macroalgae foods, feeds, and fertilizers. Getting health claims approved for foods based on macroalgae is demanding. In addition to the rules on products, the macroalgae business is strongly impacted by the elements of the general regulatory environment such as agricultural/aquacultural subsidies, maritime spatial planning and aquaculture licensing, public procurement criteria, tax schemes, and trade agreements.
\end{abstract}

Keywords Macroalgae $\cdot$ Seaweed $\cdot$ Regulation $\cdot$ Europe $\cdot$ European Union $\cdot$ Medicine $\cdot$ Food $\cdot$ Feed - Cosmetics · Fertilizer · Biofuel

\section{Introduction}

\section{Macroalgae and their uses}

Macroalgae, also called seaweed, are simple plant-like organisms found worldwide that grow in the sea along the coast, and they can also be found in freshwater ecosystems such as rivers and lakes. Macroalgae can be divided into three major groups: brown, green, and red algae, according to the photosynthetic pigmentation they have (Wang et al. 2015). Most species need

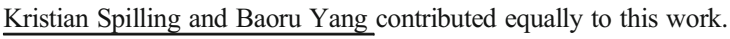

Anu Lähteenmäki-Uutela

anu.lahteenmaki-uutela@ymparisto.fi

Extended author information available on the last page of the article 
a hard substrate where to attach, but there are also mat-forming species that can be free floating, for instance some filamentous green algae that forms green tides (Gubelit et al. 2015). Different species occupy different depths from the surface/intertidal down to the depth where light becomes a limiting factor for photosynthesis. Some species are adapted to life in very sheltered bays, whereas others thrive in exposed areas with strong wave action. The brown macroalgae group Laminariales, referred as kelp, can grow up to $50 \mathrm{~cm}$ per day and be $70 \mathrm{~m}$ long forming large underwater kelp forests (Schiel and Foster 2015).

Globally, macroalgae production is more than a 6 billion USD industry (FAO 2019), of which $85 \%$ comprises food products for human consumption (FAO 2018). Most of the global production is cultivated, whereas a smaller fraction is harvested from naturally growing macroalgae. In the last decade, the global cultivation of macroalgae has doubled to approximately 32 million tons fresh weight (FW) annually, whereas the harvesting of natural macroalgae has stayed at approximately 1 million tons FW per year (FAO 2019). The vast majority (> 80\% in 2016) of macroalgae cultivation takes place in China and Indonesia. Most of the remaining production also takes place in countries in the same region: South Korea, North Korea, and Japan. There are, at least, 221 species of seaweed used for food and phycocolloid production (Zemke-White and Ahno 1999). The most cultivated species are the brown algae Saccharina japonica (Japanese kelp or kombu) and Undaria pinnatifida (Japanese wakame), the red algae Eucheuma sp., Gracilaria spp., Kappaphycus spp., and Porphyra spp. (Japanese nori), and the green algae Monostroma spp. and Enteromorpha spp. totaling $~ 90 \%$ of the cultivated FW (Lüning and Pang 2003; FAO 2019). The harvesting of wild macroalgae has traditionally been more dispersed globally with Chile and Norway being big producers in addition to China and Japan (Rebours et al. 2014; FAO 2019) and altogether 32 countries having harvesting business (Mac Monagail et al. 2017).

Macroalgae have been used as food, feed, and fertilizer for millennia. In the seventeenth century, they started to be used as a component in the industrial production of glass. Later, compounds such as carrageenan and alginate started to be extracted from macroalgae and used as a thickener in food and cosmetics (Jones and Dawes 1987). Interest in macroalgae as raw material is currently increased by the health trend in foods and nutraceuticals (Freitas et al. 2012), the naturalness trend in cosmetics (Pimentel et al. 2018), the trend towards bio-based materials to replace plastic (Lakshmi et al. 2020), and the trend towards biofuels to replace fossil fuels (Roesijadi et al. 2010). An important benefit with macroalgae is that their production does not need land, fertilization, or freshwater (FAO 2009; Rust et al. 2011; Wan et al. 2018). Macroalgae biomass is today understood as a rich source of a wide range of bioactive products of potentially high market value (Holdt and Kraan 2011; Freitas et al. 2012; Ibañez and Cifuentes 2013, Garcia-Vaquero and Hayes 2016). Relevant end uses include medicinal products, food (including food use as such, food ingredients, food supplements, and food additives), feed and feed additives, cosmetics, bioplastics, fertilizers and agricultural biostimulants, and biofuels (Joshi et al. 2015; see Skjermo et al. 2014).

In Europe, the harvesting of natural growing macroalgae has a long history and is still considerably larger in terms of tonnage than the cultivation industry. Norway is by far the largest collector of wild seaweed in Europe $(\sim 150,000$ tons per year), where in particular kelp is collected by dredging. With harvesting, it is critical to avoid overexploitation (Mac Monagail, 2017; see also FAO 2018; Vásquez et al. 2012). Norway has a long record on sustainable harvesting of Laminaria hyperborea (Svendsen 1972). Currently the Norwegian harvesting area, the coastline outside the counties of Møre or Romsdal and Trøndelag, has been divided into smaller sectors where the seaweed is allowed to be harvested in 5-year 
intervals. Adjacent sectors are not harvested the same year, and it has been estimated that the harvest is approximately $1 \%$ of the total standing stock. There have, however, been complaints by local municipalities claiming that the industry hurts local fisheries. It was suggested to increase the harvesting interval to 6-10 years, but the 5-year interval was upheld in 2019 (Forskrift om høsting av tare, Møre og Romsdal og Trøndelag 2019; see also Vea and Ask 2011).

Most of the collection of macroalgae has been for the extraction of compounds such as alginate. Beach cast algae and wild macroalgae populations have also been utilized as animal feed and fertilizer and as a source of potash, iodine, and algal polysaccharides. Currently, the most rapidly growing macroalgae segment in Europe is in the healthy "superfood" section, and macroalgae food supplements are becoming more commonly found in grocery stores. The European market of macroalgae food products is still dominated by imported products (FAO 2019). European water areas harbor a wide diversity of edible macroalgae species, many of which are currently underutilized as food and feed ingredients. However, the growing demand for macroalgae as raw material has led to more interest in macroalgae cultivation in Europe (European Commission 2017; Barbier et al. 2019), with several start-up companies as well as the traditional fish-aquaculture industry being interested in the potential of native European macroalgae species. The brown algae Ascophyllum nodosum (rockweed), Saccharina latissima (sugar kelp), Laminaria digitata (oarweed), Laminaria hyperborea (tangle, cuvie), and Alaria esculenta (winged kelp, dabberlocks) are species harvested and/or cultivated in Scotland, France, Norway, Denmark and Sweden. In the Baltic Sea, permits for the cultivation of Furcellaria lumbricalis (red algae) have been applied and cultivation of Fucus vesiculosus (brown algae, bladderwrack) is also being planned.

The legislation that applies to macroalgae products is an important part of the institutional environment for the macroalgae business in Europe. Rules on products not only impact the manufacturers of ingredients and final products but also the primary producers, i.e., the companies that harvest or cultivate the algae. In this paper, we study the European Union regulatory routes and possibilities for macroalgae-based products from the business perspective, covering products of different industrial sectors each with their own regulatory frameworks. The substantive rules and legal principles as well as the pre-market authorization or notification procedures have an impact on market access and investment payback. Ultimately, the rules have an impact on the extent and focus of macroalgae innovation.

\section{Herbal medicines}

Macroalgae have properties through which they can exert medicinal impacts. de Jesus Raposo et al. (2016) discuss the potential of the polysaccharides from marine macro- and microalgae to act as prebiotics and Fan et al. (2014) say there is an increasing interest in using marine algae protein as a source of bioactive peptides. Prebiotics are compounds, which beneficial gut bacteria use for their growth. This includes fibers that are nondigestible for humans. The Codex Alimentarius definition of dietary fiber includes oligosaccharides and polysaccharides with at least three monomer sugar units. Macroalgae include polysaccharides/fibers such as alginates and carrageenans. The dry weight of Fucus vesiculosus, for example, is half fiber (fucoidans, which are complex polysaccharides). The anti-obesity impact of Fucus is based on the insoluble fiber that enhances fermentation in the colon and improves the gut microbiota. According to the review by de Jesus Raposo et al. (2016), several different species of 
macroalgae have been documented to increase the amounts of several different beneficial microorganisms in the gut, e.g., Lactobacillus and Bifidobacterium. In addition to humans, prebiotics are beneficial for animal health (see chapter 4). Fiber in general is beneficial for blood cholesterol levels and for blood glucose levels. Bioactive peptides are short chains of amino acids, which are inert when forming part of the protein sequence but provide several beneficial health impacts, such as antioxidant, antihypertensive, and anti-inflammatory properties Beaulieu (2019), when released from the algal protein in an enzymatic process (GarciaVaquero and Hayes 2016). In addition to algal peptides, also phenolic compounds in brown algae, namely, phlorotannins, are potent bioactive compounds and possess anti-allergic, antiinflammatory, and anti-carcinogenic activity (Catarino et al. 2017). Moreover, phlorotannins are strong inhibitors of $\alpha$-glucosidase and by lowering the glucose absorption in the small intestine, provide a potential treatment for type two diabetes (Catarino et al. 2019).

The protein quality and the health-enhancing properties of macroalgae can be enhanced further by studying how the expression of genes changes under different growth conditions. The target is a tailored production and extraction of valuable molecules with potential therapeutic efficacies (Beaulieu 2019).

In the EU, medicinal products based on ingredients from macroalgae must comply with the EU law on medicines. The EU rules for human medicines are set out in Directive 2001/83/ EC. ${ }^{1}$ The definition of a medicinal product is the following:

“(a) Any substance or combination of substances presented as having properties for treating or preventing disease in human beings; or

(b) Any substance or combination of substances which may be used in or administered to human beings either with a view to restoring, correcting or modifying physiological functions by exerting a pharmacological, immunological or metabolic action, or to making a medical diagnosis." (Directive 2001/83/EC, Title I, Article 1.)

Medicines are authorized either in one of the four procedures: the centralized procedure (the European Medicines Agency evaluates the evidence and the EU Commission grants the license), the national procedure, the mutual recognition procedure, or the decentralized procedure (see European Medicines Agency web page on these procedures). In addition to the "normal" regulatory procedure for synthetic medicines, the Directive 2011/83/EC creates separate procedures for (a) herbal medicinal products and for (b) traditional herbal medicinal products. Algae are under the definition of herbal substances, and algae substances and algal preparations are herbal medicines. Herbal preparations are products of treatments such as extraction, distillation, or fermentation. The authorization of herbal medicinal products requires scientific literature to prove established medicinal use, recognized efficacy, and an acceptable level of safety. For registration as a traditional herbal medicinal product, the marketer needs to prove traditional use only, and medicinal claims cannot be made. Traditional use means at least 30 years, including at least 15 years within the EU.

An example of a traditional herbal medicine product is a powder tablet for complementing a weight loss diet for overweight patients. A tablet with $130 \mathrm{mg}$ of Fucus vesiculosus (bladderwrack) is commercially available throughout European countries. The recommended dosage is one film-coated tablet with water twice a day, taken $2 \mathrm{~h}$ before meals. The product was registered as a traditional herbal medicine in 2019. The company that registered the product does not distribute medicines itself. Instead, it licenses the registration, including the

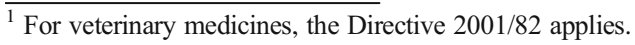


dossier, to pharmaceutical companies with their own over-the-counter brands (Diapharm company webpage 2020).

Instead of being sold as herbal medicine, a product containing a health-enhancing macroalgae-derived ingredient (e.g., a prebiotic or a bioactive peptide) may also be sold as a food supplement. While medicines treat or prevent a disease, foods can claim to improve health or to reduce the risk of disease (see chapter 3). If the product contains a specific amount of a medicinal herb for the product to have a medicinal function, the product is a classified as a medicine. The categorization depends on dosage. If it is unclear whether the product is a medicine or a food, it is to be regulated as a medicine. If the marketer is unsure whether the product is a medicine based on its function, they should ask for a classification decision from the authorities. In Europe, the national medicine agencies categorize the products on their markets (medicine vs. food). This produces differences between the EU member states. Regardless of the physiological/pharmacological impact, presenting medicinal claims will always make the product a medicine (based on the two limbs of the EU legal definition of medicine). This means that if a product claims to have a medicinal impact, it cannot be sold as food.

\section{Food and food additives}

Many edible macroalgae have high nutritional value and the environmentally friendly cultivation and harvesting methods make them appealing as raw material for food and feed (MacArtain et al. 2007; Barbier et al. 2019; Cherry et al. 2019). The small contribution that the macroalgae have in the diets of most European citizens is reflected in the relatively low level of regulation and lack of uniform EU level guidelines for macroalgae foods.

To date, no marine macroalgae species has been found harmful to human health. Thus, a vast variety of different macroalgae species could be considered potential raw material for food and feed (Biancarosa et al. 2017). Moreover, macroalgae harbor compounds with reported bioactive properties, and macroalgae extracts are commonly used in food supplements (GarciaVaquero and Hayes 2016). However, all the edible macroalgae species are not authorized as food or food supplements in the EU. The consumption history of these species affects their regulatory status. The entry of macroalgae species and extracts to the market is regulated by the Novel Food Regulation, which states that species having not been used as food to a significant degree in any of the EU member countries before 15th of May 1997 need to undergo an authorization procedure in order to ensure their safety for human consumption (Regulation (EC) No 258/97). In the new Novel Food Regulation (EC) 2015/2283, an additional notification system is provided for species that have demonstrated history of safe food use for at least 25 years in a country outside the EU. The notification system may provide an easier route to the EU market for some cosmopolitan macroalgae species that have not been used in Europe but are consumed elsewhere.

The European Commission, through the Regulation (EU) 2017/2470, maintains an online list called the Novel Food Catalogue that contains the Union's list of all authorized novel foods. This legislation applies to macroalgae species intended to be used as food. Thus, the list contains information of the species whose status as novel food has been inquired and assessed. The list is non-exhaustive and is based on information collected from the member countries. The Novel Food Catalogue comprises both European and imported seaweeds, and till the end of 2020, there are 22 seaweed species listed. Of these, only one species, Sphaerotrichia 
divaricata, is considered a novel food that needs to undergo safety assessment and authorization procedure before it can enter the EU market. The accepted macroalgae species in the Novel Food Catalogue include the most commonly used European red (e.g., Gracilaria verrucosa, Porphyra tenera, Palmaria palmata), brown (e.g., Alaria esculenta, Fucus vesiculosus, Saccharina latissima), and green (e.g., Enteromorpha sp., Ulva lactuca, Monostroma nitidum) algae species. Some edible species are, however, still missing. The genera Ulva and Monostroma, for example, have multiple species that have great potential as food due to their high content on proteins and polyunsaturated fatty acids (Garcia-Vaquero and Hayes 2016; Gubelit et al. 2015). To date, only two macroalgae products, fucoidan extracts from Fucus vesiculosus and Undaria pinnatifida, have been accepted as novel foods for use in foods and food supplements. In addition, phlorotannins extracted from brown alga Ecklonia cava has been authorized as a novel food for use in food supplements only (Commission Regulation (EU) 2017/2470).

Although macroalgae do not produce endogenous toxins, a major food safety concern associated to macroalgae products is the presence of toxic contaminants such as heavy metals (cadmium, lead and mercury) and arsenic transmitted to the macroalgae from their growth environment (Suutari et al. 2017). Due to their characteristic cell wall structure, macroalgae readily accumulate heavy metals from the surrounding water (MacArtain et al. 2007). This ability sets requirements for the water quality at the sea areas and water bodies where macroalgae are cultivated or harvested for human or animal consumption.

The Commission Regulation (EC) No 1881/2006 on contaminants sets maximum levels for certain toxic substances like heavy metals for certain foods. Due to the relatively minor contribution of macroalgae-based food products in the diets of most EU citizens, the regulation of toxic contaminants in macroalgae-derived foods has not been extensive in the EU. Thus, the EU has not set maximum levels for cadmium or inorganic arsenic, both of which are commonly present at varying amounts in macroalgae food products (Almela et al. 2006; Biancarosa et al. 2017). The same applies for mercury, which lacks the maximum limit set by EU. However, the Regulation (EC) No 396/2005 on maximum residue levels of pesticides in food and feed defines a maximum level for mercury in algae and prokaryotic organisms at $0.01 \mathrm{mg} / \mathrm{kg}$, which is a default for organisms for which the maximum residue level has not been specifically determined. The regulation does not state if the content of mercury is calculated per fresh weight or per dry weight of the macroalgae. Nevertheless, the limit is very low compared to maximum levels of mercury set for other consumable marine organisms in the Commission Regulation (EC) No 1881/2006 and forms as such a market barrier for most macroalgae-derived food products. For comparison, the maximum level for mercury in most fishery products is $0.5 \mathrm{mg} / \mathrm{kg} \mathrm{FW}$ and $1.0 \mathrm{mg} / \mathrm{kg}$ for the meat of certain fish species (Commission Regulation (EC) No 1881/2006). In the case of food supplements, maximum limits for toxic contaminants have been defined, and are generally higher than the corresponding levels set for other foodstuff as the expected daily consumption of food supplements is much lower than the amount of food consumed. Commission Regulation (EC) No 1881/2006 defines a maximum limit of $3.0 \mathrm{mg} / \mathrm{kg}$ for cadmium in food supplements consisting exclusively or mainly of dried seaweed or of products derived from seaweed. For mercury and lead, maximum levels for food supplements in general are set to $0.1 \mathrm{mg} / \mathrm{kg}$ and $3.0 \mathrm{mg} / \mathrm{kg}$, respectively.

On 19 March 2018, the European Commission gave a recommendation to the member countries to monitor the levels of cadmium, lead, mercury, arsenic, and iodine in macroalgae food and feed products and food additives (Commission Recommendation (EU) 2018/464). 
Monitoring is carried out to support a dietary exposure assessment and may lead to further regulation of the toxic contaminants in macroalgae products. The recommendation and the dietary exposure assessment are topical, considering the weaknesses of the macroalgae regulation. Instead of the current default limit of $0.01 \mathrm{mg} / \mathrm{kg}$, a more reasonable maximum level for mercury, based on risk assessment using a realistic estimation of consumption of macroalgae, would support the growth of macroalgae food industry within the EU. Moreover, the total arsenic content in food and feed products is a poor indicator of the health risks related to the macroalgae food products. Based on the current knowledge, most of the arsenic in macroalgae is incorporated to organic molecules such as arsenosugars (Edmonds and Francesconi 2003) and is less harmful to humans and animals than the inorganic forms of arsenic, which are toxic (Almela et al. 2006). As the ratios of inorganic and organic arsenic vary between different macroalgae species (Almela et al. 2006), the content of inorganic arsenic should be regulated separately instead of establishing maximum levels for total arsenic content.

Pharmaceutical substances such as antibiotics used in fish aquaculture have been shown to accumulate in macroalgae that are grown together with fish in an integrated multi-trophic aquaculture (IMTA) (Rosa et al. 2020). Although the maximum levels for these pharmaceuticals have been defined for fish, such limits have not been set for macroalgae (Regulation (EC) 37/2010). If pharmaceuticals are used in IMTA, the suitability of the macroalgae for food use should be considered.

Macroalgae have a long history of usage in the production of thickening and gelling agents applied as additives in food, cosmetics, and pharmaceuticals. The use of food additives in the EU is controlled by the Regulation (EC) No 1333/2008, containing a list of authorized food additives and comprises eight macroalgae-derived additives under codes E401-E407a. Commission Regulation (EU) No 231/2012 further specifies the origin, composition, and usage of the accepted additives. A wide variety of brown and red algae are accepted for the extraction of thickening and gelling agents like alginates, agar and carrageenan. The composition and features of the extracted additives vary between algal species. Some novel or underutilized macroalgae species could be used for production of food additives, although they would not be accepted as food or food ingredients as such. In addition to the traditional macroalgae-derived thickening and gelling agents, macroalgae contain pigments, antioxidants, and bioactive compounds, the properties and potential applications of which are under active research (Holdt and Kraan 2011; Aryee et al. 2018; Jacobsen et al. 2019). However, any novel macroalgae-derived phytochemicals intended for use as food additives, food ingredients, and food supplements require an authorization before their entry to the EU market.

Organic macroalgae are a specific regulatory category, and the Commission Regulation (EC) No 710/2009 lays down detailed rules on organic macroalgae production. The new Regulation (EU) 2018/848 on production and labelling of organic products will come into force from the beginning of 2021. The regulation defines the rules for production of organic algae, including harvesting of natural stocks as well as cultivation of macroalgae (Part III: Production rules for algae and aquaculture animals, 2. Requirements for algae). The collection of wild algae and their parts are considered organic production provided that the growing areas are suitable from a health point of view and of high ecological status as defined by Water Framework Directive 2000/60/EC, the collection does not affect significantly the stability of the natural ecosystem or the maintenance of the species in the collection area, and harvesting can be carried out without causing a significant impact on the state of the aquatic environment. Organic algae aquaculture at sea may only utilize nutrients naturally occurring in the 
environment, or from organic aquaculture, preferably located nearby as part of a polyculture system, i.e., organic macroalgae production cannot be integrated with non-organic fish production. Culture density or operational intensity should be recorded to maintain the integrity of the aquatic environment by ensuring that the maximum quantity of algae can be supported without negative effects on the environment.

The regulation, monitoring, and labeling of macroalgae products on the market is convoluted by difficulties in the identification of macroalgae species especially what comes to dried or processed algae products. Due to high phenotypic plasticity and similar appearance of closely related species, the identification of macroalgae by morphological features is not always possible and requires investigation of genetic markers. This poses a challenge also to monitoring the compliance to the Novel Food Regulation. For example, food products containing algae of the genera Ulva or Porphyra often contain algae material from multiple different species. This issue will be partly covered by the on-going work of a technical committee "CEN/TC 454-Algae and algae products" that has been set by European Committee for Standardization (CEN) in 2017 to develop standards and practices for algae and algae-based products. The committee will define specifications for sampling methods for algal products on different sectors of industry including food, feed and cosmetics. Also, special requirements are set for the labeling and marketing of macroalgae and macroalgae products sold as food, since they are included in the Regulation (EU) No 1379/2013 on the common organization of the markets in fishery and aquaculture. According to the regulation, the origin and production or harvesting method needs to be indicated. Moreover, macroalgae species marketed in the member countries must be listed in the national register of fishery and aquaculture products with their commercial designations and scientific names. There is large variation in the lists among the member states especially what comes to the authorized macroalgae species and their designation practices. These lists are maintained and updated by national authorities based on the request of the food business operators, and it is expected that when macroalgae food products become more popular in the EU member countries, more macroalgae species and market designations will be included in the lists.

Medicinal claims cannot be used for foods. Nutrition and health claims for foods (including food supplements) are regulated at the EU level (Regulation EC/1924/2006), where EFSA evaluates the scientific evidence supporting the claims. Nutrition claims are allowed if they are listed in the Annex of the Regulation. An example of an allowed nutrition claim is "high fiber" (on the condition that the product contains at a minimal level of 6-g fiber per $100 \mathrm{~g}$ ). For vitamins and minerals, there are similar rules. The nutrition claim "source of vitamin/mineral $\mathrm{x}$ " or "contains vitamin/mineral x" can be used, if the product contains a significant amount of the vitamin/mineral. A significant amount is minimally $15 \%$ of the recommended daily allowance in $100 \mathrm{~g}, 100 \mathrm{~mL}$, or a portion if the packaging contains only one dose portion (i.e., if the packaging contains several portions, the significant amount must be in $100 \mathrm{mg}$ or $100 \mathrm{~mL}$ ). For drinks, $7.5 \%$ of the recommended daily allowance (RDA) in $100 \mathrm{~mL}$ suffices for the claim "source of vitamin or mineral x." The RDAs for vitamins and minerals are defined in the Annex XIII of the Nutrition Information Regulation (EU) 1169/2011. The RDA for iodine, for example, is $150 \mu \mathrm{g}$. For macroalgae-derived foods, the claim "source of iodine" can thus be used if the iodine content reaches the level of $22.5 \mu \mathrm{g}$ per $100 \mathrm{~g}, 100 \mathrm{~mL}$, or per dose. For a claim "high in mineral x," the content of mineral needs to be doubled; i.e., for iodine, the claim "high in iodine" requires the iodine content of $45 \mu \mathrm{g}$ per $100 \mathrm{mg}, 100 \mathrm{~mL}$, or dose. For an iodine drink, $11.25 \mu \mathrm{g}$ per $100 \mathrm{~mL}$ is the minimum. For food supplements, the rules are the same as for normal foods. An iodine supplement must contain a significant amount of iodine in 
the daily dose as instructed. If the food supplement is marketed as an excellent source of iodine, the iodine content must be double as high. Macroalgae are likely to become increasingly interesting for consumers as the only non-animal source of long chain omega-3 polyunsaturated fatty acids (omega-3 PUFAs) eicosapentaenoic acid (EPA) and docosahexaenoic acid (DHA), in addition to microalgae. Further, the relative high abundance of phospholipids makes the macroalgae a very attractive source of phospholipids rich in omega-3 PUFAs. According to Regulation (EC) 1924/2006, the nutrition claim "source of omega-3 fatty acids" can be made if the product contains at least $0.3 \mathrm{~g}$ alpha-linolenic acid (ALA) per $100 \mathrm{~g}$ and per $100 \mathrm{kcal}$, or at least $40 \mathrm{mg}$ of EPA + DHA per $100 \mathrm{~g}$ and per $100 \mathrm{kcal}$. For the claim "high omega-3 fatty acids," the amounts must be double as high.

At least one company has applied for the following health claims for macroalgae to be authorized by the EU:

- Seaweed fibers support body detoxification.

- Seaweed fibers rid toxins from the body.

- Seaweed fibers aid colonic health.

- Seaweed fibers protect the colon.

- Seaweed fibers can detox the body.

- Seaweed fibers help maintain a healthy colon.

- Seaweed fibers promote healthy conditions in the colon.

As the food was not sufficiently characterized for a scientific assessment of the claimed effect, the claim could not be substantiated (EFSA opinion 2011; 9(4):2083). The claim and its alternative claims were therefore not authorized by the EU Commission.

A health claim has also been applied for calcium as a citrate salt derived from the red seaweed Lithothamnion corallioides, sold under trade name Aquamin S. The claim and its alternative wordings were:

- Calcium promotes a healthy heart.

- Calcium maintains a healthy heart.

- Calcium helps build a healthy heart.

- Calcium helps promote a healthy heart

The application resulted in non-authorization by the EU Commission. The scientific evidence provided was insufficient to substantiate the claimed effect for the food in question (EFSA opinion 2009; 7(9), 1210). Getting health claims approved in EU takes a significant amount of both time and resources from an entrepreneur. Therefore, a less demanding marketing strategy with macroalgae health foods and health-enhancing food supplements is to use nutrition claims only.

\section{Feed and feed additives}

Due to their high content of minerals, especially iodine, macroalgae have traditionally been used as animal feed and feed supplements. Macroalgae constitute a sustainable aquafeed ingredient due to their high protein content and high growth rate (Mustafa et al. 1995). It has been shown that the use of macroalgae in finfish feeds can enhance the growth rate, 
physiology, stress resistance, immune system, and flesh quality of the fish (Wan et al. 2018). Ulva lactuca and Pterocladia capillacea (Valente et al. 2006) and Gracilaria sp. and Ulva rigida (Wassef et al. 2013) are suitable as additional feed component for the enhancement of the European seabass (Dicentrarchus labrax) at inclusion levels between 5 to $10 \%$ in the feed. Also, Ascophyllum nodosum, Porphyra yezoensis, or Ulva pertusa can be used to feed the red sea bream fingerlings (Pagrus major) at levels of 5\% of the fish meal (Mustafa et al. 1995). Studies on the use of macroalgae to feed Nile tilapia have shown that species such as Ulva rigida and Cystoseira barbata can be used as feed ingredients (Ergün et al. 2009; Güroy et al. 2009).

In ruminant diet, the macroalgae Ascophyllum nodosum acted as a prebiotic and resulted in an enhancement of growth (Bach et al. 2008; Dierick et al. 2009). Moreover, macroalgae feed has been reported to decrease the ruminant methane emissions (Maia et al. 2016). Such information can be used in marketing claims related to low-carbon dairy. The use of a mixture of the three macroalgal species (Ulva rigida, Sargassum muticum, and Saccorhiza polyschides) as a mineral supplement for feeding organic dairy cattle improved the mineral status of the animals, particularly the levels of iodine and selenium in milk (Rey-Crespo et al. 2014). Iodine-rich milk products, for example, can be marketed to people with iodine deficiencies (Dierick et al. 2009) (see chapter 3).

There are some European companies that offer macroalgae products made of Ascophyllum nodosum (Norwegian kelp) to be used as meal for fish, horses, pigs, and ruminants. This brown seaweed has a long record for animal feed use due to its high content on fatty acids, polyphenols, peptides, and polysaccharides such as alginic acid (28\%), fucoidan (11.6\%), laminarin (4.5\%), and mannitol (7.5\%), not found in terrestrial plants (Karatzia et al. 2012).

The accepted feed materials in the EU, including algae meals as well as algae oil and extracts, are defined in the Commission Regulation 68/2013. Maximum levels of toxic contaminants in animal feed are defined in the Directive 2002/32/EC. In macroalgae feed materials specifically, maximum level has been defined only for arsenic at $10 \mathrm{mg} / \mathrm{kg}$ in complete and complementary feed for pet animals, and at $40 \mathrm{mg} / \mathrm{kg}$ for macroalgae meal and macroalgae derived feed materials (Directive 2002/32/EC). Moreover, upon request, the feed operator must demonstrate that the content of inorganic arsenic is lower than $2 \mathrm{mg} / \mathrm{kg}$. For lead, cadmium and mercury, the maximum levels in feed materials in general are $10 \mathrm{mg} / \mathrm{kg}, 1$ $\mathrm{mg} / \mathrm{kg}$ and $0.1 \mathrm{mg} / \mathrm{kg}$, respectively (Directive 2002/32/EC). Values are given per weight relative to a feed with a moisture content of $12 \%$.

\section{Cosmetics}

Macroalgae may provide ingredients for cosmetic products that respond to the interest in natural products, sustainability, and the marine world image (Couteau and Coiffard 2016; Wang et al. 2015). The population is getting older, and there is an increasing concern of how to improve our lifestyle in health and well-being, especially healthy aging (Nohynek and Antignac 2010). In addition, consumers are more aware of the origin of the products, the manufacture processes, and their ecological implications, and thus, there is an increasing development in biotechnology and beauty industry (Zappelli et al. 2016). Macroalgae are rich in biologically active compounds such as polysaccharides; proteins, peptides, and amino acids; lipids (fatty acids); vitamins (E, B1, B2, B3, B5, B6, B12, B8, B9, and C) and minerals; and pigments (chlorophylls, carotenoids, xanthophylls, and phycobiliproteins) and phenolic 
compounds (Pimentel et al. 2018). For example, polysaccharides, peptides, carotenoids, and fatty acids have antiaging and antioxidant activities, and mycosporine-like amino acids, present in red algae, have antiphotoaging activity (Zhang et al. 2010; Bedoux et al. 2014). Hence, the possible uses of macroalgae in cosmetics are wide-covering products for skin care, hair care, and oral care as well as make-up products and deodorants (Bedoux et al. 2014; Ariede et al. 2017; Pimentel et al. 2018). According to Couteau and Coiffard (2016), the product categories where macroalgae are most commonly applied are moisturizing and antiaging products. The relevant bioactivities of macroalgae and macroalgal extracts include antioxidant, UV/photo-protective, whitening/melanin-inhibitory, anti-inflammatory, anticellulite treatment and slimming, and antiviral and antibacterial effects (Pimentel et al. 2018). The macroalgal species, used in cosmetics, include Alaria esculenta (winged kelp, brown algae), Chondrus crispus (Irish moss), Ulva lactuca (sea lettuce), Postelsia palmaeformis (sea palm), and Fucus vesiculosus (Verdy et al. 2011; Joshi et al. 2018).

There are European companies that have commercialized macroalgae-based cosmetics, for example, based on natural oils and antioxidants extracted from the red algae Furcellaria lumbricalis that naturally grows in the Baltic Sea (Bučas et al. 2007). In addition, phycoerythrin, an abundant photosynthetic pigment in Furcellaria, is used for colorants in cosmetics and foods (Dumay et al. 2014).

Regulation 1223/2009/EC on cosmetic products contains the basic EU rules on cosmetics. There is a centralized notification procedure for all cosmetic products to be placed on the EU market. Manufacturers and importers notify the products via the EU portal (Cosmetic Products Notification Portal, CPNP). The legal responsibilities include product safety assessment, keeping product information file (PIF), and reporting serious undesirable effects. There are binding lists of ingredients that are acceptable, restricted, and prohibited. The EU's Cosmetic Ingredient database, CosIng (https:/ec.europa.eu/ growth/tools-databases/cosing/index.cfm), contains the legal requirements and restrictions on each substance. Fucoidan, for example, is an accepted ingredient used as an antioxidant and for skin conditioning. The centralized and science-based process with free movement of goods between the EU member states creates a clear regulatory environment for cosmetics companies. The regulatory capability of the EU in the field of cosmetics is well defined, and thus, Europe is called the "undisputed regulatory hegemon" (Bach and Newman 2010, 688), with other countries copying the EU lists and rules (Zakaria 2015).

Commission Regulation 655/2013 of 10 July 2013 lays down the criteria for the justification of claims used in cosmetics marketing. There are six criteria: legal compliance, truthfulness, evidential support, honesty, fairness, and informed decision-making. Claims for cosmetic products, whether explicit or implicit, shall be supported by "adequate and verifiable evidence." Presentations of a product's performance shall not go beyond the available supporting evidence. Specific criteria for natural and organic claims have been considered, but as the ISO has developed standards for these products, duplicate work has not been started at the EU (European Commission 2015). ISO 16128-1:2016 provides guidelines on definitions for natural and organic cosmetic ingredients, and ISO 16128-2:2017 describes the quality criteria for ingredients and products. Although ISO standards are not laws and do not have legal power as such, adopting an ISO standard and referring to it in labelling makes it binding between the marketer and the consumer. 


\section{Packaging materials}

Some plastic products are increasingly considered problematic, particularly due to their marine litter impacts. At the European level, the Regulation EU 2019/904 on single-used plastic materials bans single-use plastic plates, cutlery, straws, balloon sticks, and cotton buds by 2021. Biomaterials are an attractive alternative to plastic since they are biodegradable and can be derived from biological sources such as plants, macroalgae, animals, and microbial sources causing less impact on the environment. Among these, macroalgae are gaining interest of research and business as bioplastic product for food packaging materials due to the high biomass they can reach and the wide range of natural environments possible for their cultivation. In addition, macroalgae contain $25-60 \%$ dry weight of polysaccharides including mannan, ulvan, carrageenan, agar, laminarin, mannitol alginate, and fucoidan (McCandless 1981), which can be effectively utilized for bioenergy and synthesis of biomaterials (Mesquita Marques 2017). In Germany, for example, macroalgae are grown in artificial seawater in land-based systems (due to lack of space in the North Sea) and developed into biodegradable and even possibly edible carton-like packaging materials (PackagingEurope.com 2019).

According to a consensus statement on the hazardous chemicals that migrate to foods from packaging materials (Muncke et al. 2020), chemical safety is sometimes ignored when developing recycled non-plastic materials, and the current EU regulatory system on food contact materials does not adequately protect consumers. Because of this, most humans are subjected to chemicals that cause chronic diseases, and children, by being particularly vulnerable, are put at risk. The EU Regulation on Food Contact Materials (EC/1935/2004) does state that the use of food contact materials must be based on scientific risk assessment. The regulation requires that "materials do not release their constituents into food at levels harmful to human health" (Article 3(1)(a)). In 2016, over 8000 chemicals were listed in the EU and member state lists of authorized chemicals in food contact materials (Simoneau et al. 2016). According to Muncke et al. (2020), the lists include chemicals that are known hazardous. Toxicity and exposure information exists only for few of the chemicals that are intentionally added but assessing the risks is particularly difficult with the non-intentionally added substances (Muncke et al. 2017). The scientific consensus on the need for a regulatory reform may lead to stricter EU rules in the future, and packaging materials derived from macroalgae must comply with the general rules.

Green macroalgae are seen as good candidates for packaging materials (Lakshmi et al. 2020). An interesting green macroalgae-derived product is ulvan (Lahaye and Robic 2007), a sulfated polysaccharide extracted from the cell wall of green seaweed Ulvales. This polysaccharide can be used for the preparation of some biomaterials such as films, fibers, scaffolds, absorbents, gels, and stabilizer (Lakshmi et al. 2020), of which potential applications cover the field of food, pharmaceutical, agricultural, and medical industry (Tziveleka et al. 2018). The active films seem to be a promising alternative for packaging due to their natural and nontoxic source and due to their optical, structural, thermal, and antioxidant properties (Guidara et al. 2019). The antioxidant properties of ulvan are an added value to the product, which is crucial for active food packaging and enhances the shelf life of food (Ganesan et al. 2018). 


\section{Fertilizers and biostimulants}

Today, the global phosphorus and nitrogen reserves are very inefficiently used. Nitrogen fertilizer is traditionally extracted from the nitrogen gas in air, using natural gas in the HaberBosch process, which is energy intensive. Phosphorus fertilizer is mainly extracted from mined phosphorus rock, and although there are still large reserves, it is a finite resource. Macroalgae can be utilized in capturing nutrients in nutrient-rich sea areas and in waste-water streams and transforming them into organic fertilizer.

Macroalgae have traditionally been collected and used as fertilizers. In Europe for example, Palmaria palmata and kelp (Laminaria digitata) have been used as fertilizers on the west coast of Ireland for hundreds of years. Beach cast macroalgae and side streams of the macroalgae industry have been suggested as possible raw material for organic fertilizers (Zodape 2001), and currently, macroalgae are under investigation as biofertilizers or biostimulants. The nutrient-rich algal biomass with high content of organic material and inorganic nutrients can be used directly as an organic fertilizer to the soil (Tabarsa et al. 2012), or nutrients can be extracted from the biomass. For example, the green macroalgae Ulva sp. is a potential candidate for producing high-quality compost for agricultural crop production (Wosnitza and Barrantes 2006; Cole et al. 2016). Another study proved the utility of solid residuals obtained from biogas production by mixing Ulva sp. and organic matter (cow dung) as an organic fertilizer for growing mung beans (Akila et al. 2019). Torres et al. (2019) summarized some beneficial effects in plants by using seaweed as fertilizers.

The heavy metal content poses some restrictions to the use of macroalgae as biofertilizer (see Sharma et al. 2014). Depending on the water quality at their growth site, macroalgae may accumulate notable quantities of heavy metals potentially restricting their use in agriculture. Maximum levels for various heavy metals (cadmium, hexavalent chromium, mercury, nickel, lead and inorganic arsenic $)^{2}$ in fertilizers have been defined in the Regulation EU 2019/1009. In the study of Franzén et al. (2019) on the potential use of seaweed beach cast in Gotland as biofertilizer, the cadmium content in the seaweed varied between 0.13 and $2.2 \mathrm{mg} / \mathrm{kg}$ depending on the collection site and species composition of the beach cast. However, also higher cadmium levels in the Baltic Sea seaweeds have been found (Greger et al. 2007). The current maximum level for cadmium in sewage sludge biofertilizers in Sweden is $2 \mathrm{mg} / \mathrm{kg}$ (Regulation 1998: 944), whereas a limit of $0.8 \mathrm{mg} / \mathrm{kg}$ has been proposed for the year 2030 by the Swedish Environmental Protection Agency (Swedish-EPA 2013). Moreover, the newly established maximum level for cadmium in biofertilizers in the EU is $1.5 \mathrm{mg} / \mathrm{kg}$ (Regulation EU 2019/1009). Thus, although macroalgae are a promising optional raw material for production of biofertilizers, the harvesting site and species composition must be taken into account to avoid harmful concentrations of heavy metals restricting the use of fertilizers in agriculture. Mixing the macroalgae biomass with other biofertilizers could be a solution to reduce the content of toxic contaminants.

\footnotetext{
2 In organic fertilizer (same for biostimulants):

Cadmium $1.5 \mathrm{mg} / \mathrm{kg}$

Chromium $2 \mathrm{mg} / \mathrm{kg}$

Mercury $1 \mathrm{mg} / \mathrm{kg}$

Nickel $50 \mathrm{mg} / \mathrm{kg}$

Lead $120 \mathrm{mg} / \mathrm{kg}$

Inorganic arsenic $40 \mathrm{mg} / \mathrm{kg}$
} 
The European Biostimulant Industry Council (EBIC 2012) has defined agricultural biostimulants (ABs) as substance that "act on the physiology of the plant through different pathways to improve crop vigor, yields, quality and post-harvest shelf life/conservation." Macroalgae and their extracts have a long record on being used as soil conditioner to improve crop yield (Booth 1969; Temple and Bomke 1988). In addition, macroalgal biostimulants have been shown to stimulate the plant growth and yield with beneficial effects on root development and mineral absorption, enhancement of plant chlorophyll, on crop yield, and on resistance to environmental and biotic stresses (Zhang 1997; Khan et al. 2009; Sharma et al. 2014). Brown macroalgae, such as Ascophyllum nodosum, Ecklonia maxima, Fucus serratus, Laminaria digitata, L. hyperborea, Macrocystis pyrifera, and Sargassum spp., are commonly used for biostimulants production (Boney 1965; Sharma et al. 2014). They are rich in polysaccharides such as alginates, fucoidans, and laminarin that enhance the natural defense response of plants (van Loon and van Strien 1999; Vera et al. 2011). For example, alginate enhances the soil properties by increasing the growth of microbes and fungi (Khan et al. 2009). Also, macroalgae present hormonal substances such as cytokinin (Stirk et al. 2003), which is linked to the nutrient mobilization in vegetative and reproductive organs of the plant (Featonby-Smith and van Staden 1984).

In 2016, the value of global macroalgae biostimulant market was 483 million euros, of which the European market accounted for approximately $40 \%$ with market value of 194 million euros and is thus the largest market for macroalgae-based biostimulants (https:// www.biostimulants.eu). Partly due to governmental encouragement to use sustainable farming practices, the European market of biostimulants is estimated to grow 10-12\% annually (Bio4safe project, EBIC 2012). However, the European biostimulant market has suffered from the lack of uniform legislation and official definition of biostimulants. Until recently, every EU member state has applied its own policies in regulating the acceptance, marketing, and use of biostimulants in agriculture. This has made it difficult and time consuming for the producers to extend their business to other countries within the EU. Considering the fast-growing market for biostimulants, the Regulation EU 2019/1009 is timely, as it lays down a common definition and regulations also for biostimulants. The common EU regulation removes barriers for biostimulant producers as well as for farmers. In the regulation, biostimulants are defined as "products that stimulate plant nutrition processes independently of the product's nutrient content by improving plant's nutrient use efficiency, tolerance to abiotic stress, quality traits, or availability of confined nutrients in soil or rhizosphere." Authorization is required for biostimulants, and a positive EU list of accepted biostimulants will be created. Maximum limits for heavy metals are defined in the regulation and are identical to the ones set for biofertilizers. Only scientifically proven properties may be declared in the label of biostimulants. The European Committee for Standardization (CEN) is developing standards to support the implementation of the Regulation, and Ricci et al. (2019), propose some general principles for justifying plant biostimulant claims, e.g., the number of field trials required for each crop.

\section{Biofuel}

The revised Renewable Energy Directive (EU 2018/2001) and EU Member State rules have increased the demand for biogas and bioethanol. The Commission sees both renewable biofuels and electric vehicles as solutions for transport decarbonization. The EU Member 
States must source $10 \%$ of transport fuels from renewable sources by 2020 . The biofuel transition can potentially cause indirect land use changes globally, if food crops are replaced by fuel crops. This may in turn lead to forests, wetlands, and peatlands being turned into agricultural land, and more $\mathrm{CO}_{2}$ being released. In 2019, the EU gave its Delegated Regulation on Indirect Land-Use Change (EU) 2019/807 on the sustainability criteria for biofuels. The goal is to identify those with a high risk of indirect land use change, and to certify those with a low risk.

The carbohydrate-rich macroalgae are a promising source of third generation biofuels, which, by definition, do not require agricultural land for production, and hence do not compete with food crops for the land or fresh water resources. At present, biogas production is an energetically and economically more feasible option than producing biodiesel as biogas does not require drying and lipid extraction unlike biodiesel. However, even the global macroalgae production (ca. $32 \mathrm{Mt} / \mathrm{a}$ ) could not significantly contribute to the goal of the Environment Committee of the European Parliament according to which "advanced biofuels sourced from seaweed or certain types of waste should account for at least $1.25 \%$ of energy consumption in transport by 2020" (European Parliament News 2015). If this goal was to be reached through utilizing macroalgae only, Europe would need $168 \mathrm{Mt}$ of macroalgae per annum (Jacob et al. 2016).

The reported biogas yields of macroalgae are generally between 100 and $400 \mathrm{~m}^{3} / \mathrm{t} \mathrm{VS}$, but their high growth rates per unit of water area make macroalgae superior to terrestrial energy crops in total methane potential ( $\mathrm{m}^{3} / \mathrm{ha}$ ) (Murphy et al. 2015). The species (e.g., $\mathrm{C}: \mathrm{N}$ ratio), cultivation conditions (e.g., season, geographical location, nutrient concentrations), harvesting (cast vs. cultivated), and pretreatment of the biomass (e.g., maceration, drying) determine the biogas yields derived from macroalgal biomass. The optimal $\mathrm{C}: \mathrm{N}$ ratio of biogas feedstock is between 20:1 and 30:1. Most of the brown algae fall within this range while red and green algae do not (C:N<20) (Jard et al. 2013), and hence, brown algae produce generally higher methane yields. However, C:N ratio is not stable and varies with the macroalgae composition, the season (i.e., with light, temperature, and other growth factors), with dependence on the bioconversion factors used (Torres et al. 2019). Thus, the harvesting should be optimized to coincide with the highest biomass yield and $\mathrm{C}: \mathrm{N}$ ratio, and consequently the highest $\mathrm{CH}_{4}$ yield. In addition, by treating the macroalgal biomass prior to the anaerobic digestion, the biogas yields can be improved (Saratale et al. 2018).

Using macroalgal biomass for biogas production has multiple bottlenecks. The seasonality leads to an uneven supply of biomass in both quantity and quality, the harvesting and pretreatment of the biomass are energy intensive, and the high concentrations of phenols, heavy metals, sulfides, salts, and volatile acids may inhibit biomethanation. Therefore, profitable biogas production solely from macroalgae is not yet feasible (Nielsen and Heiske 2011; Tedesco et al. 2014). More sustainable and economically viable approaches include co-digestion with other feedstocks, and most importantly, integrated strategy for algae cultivation and co-production of multiple high-value products (i.e., biorefinery) or a combination of these. Co-digestion with other feedstocks (e.g., grasses and slurries) reduces the problems listed above by improving the C:N ratio and nutrient balance and diluting the concentrations of inhibitory compounds leading to higher biogas yield (Nielsen and Heiske 2011; Jard et al. 2013). In the biorefinery concept, the revenue is mostly originating from the extracted high-value compounds such as biologically active compounds, whereas the residual biomass is used for biogas 
production (Balina et al. 2017; Torres et al. 2019). After the anaerobic digestion, the residual biomass can be exploited as organic fertilizer given that the requirements set by EU (Regulation EU 2019/1009) are met (see chapter 7).

In 2015, a Danish company commenced biogas production (6 million $\mathrm{m}^{3}$ biogas/a) from beach cast seaweed, food waste, and manure. The food waste includes by-products from carrageenan production plant, which links the plant also to the refinery concept. The benefits of using cast seaweed include the removal of foul odors from the beaches, improving marine environment, and reductions in $\mathrm{CO}_{2}$ associated with energy production (Solrød Kommune 2014).

\section{Discussion and conclusions}

Macroalgae have several properties that make them interesting for developing innovative products. The substantive and procedural rules for products should protect human health and consumer rights while not being overly burdensome for European or third-country entrepreneurs.

EU directives set common objectives for all member states, but states may decide how to reach the goals. Directives may lead into some degree of discrepancy. EU regulations, in turn, are directly applicable in member states; i.e. they do not require implementation at member state level. Harmonized EU rules clarify the operating space for all stakeholders. Centralized procedures for novel foods, food additives, feed substances, cosmetic products, and fertilizers/biostimulants along with the development of methodologies for safety evaluation at the EU level help in realizing the single market for products.

In this paper, we have identified and discussed the current EU legislation on macroalgae products as well as the bottlenecks or uncertainties from a company perspective, which are summarized in Table 1. Outside Europe, all countries have their own rules (see Holdt and Kraan 2011). Product regulations as part of the institutional environment of each market area will impact the product development efforts and market selection of companies. From a consumer perspective, regulations and regulatory differences impact the assortment of products available.

In addition to the regulations discussed above, which directly regulate the production and marketing of macroalgae products, the markets for macroalgae products are also shaped by more general regulatory instruments impacting either the supply of macroalgae products or their demand. Maritime spatial planning has a role for enabling blue bioeconomy, and the efficiency and fairness of cultivation licensing are critical for the business. In Europe, the cultivation rules are based on EU environmental and water laws, but the licensing procedures are national or regional. Many macroalgae products have their added value in replacing more resource-demanding and high-carbon alternatives. A regulatory framework that adds weight on sustainability criteria will work in their favor:

- Removing the subsidies from the production of competing, high-carbon raw materials will lower the relative prices of more sustainable products.

- Public procurement rules can add weight to environmental criteria, creating markets for eco-innovative products. European procurement policies are based on European and 


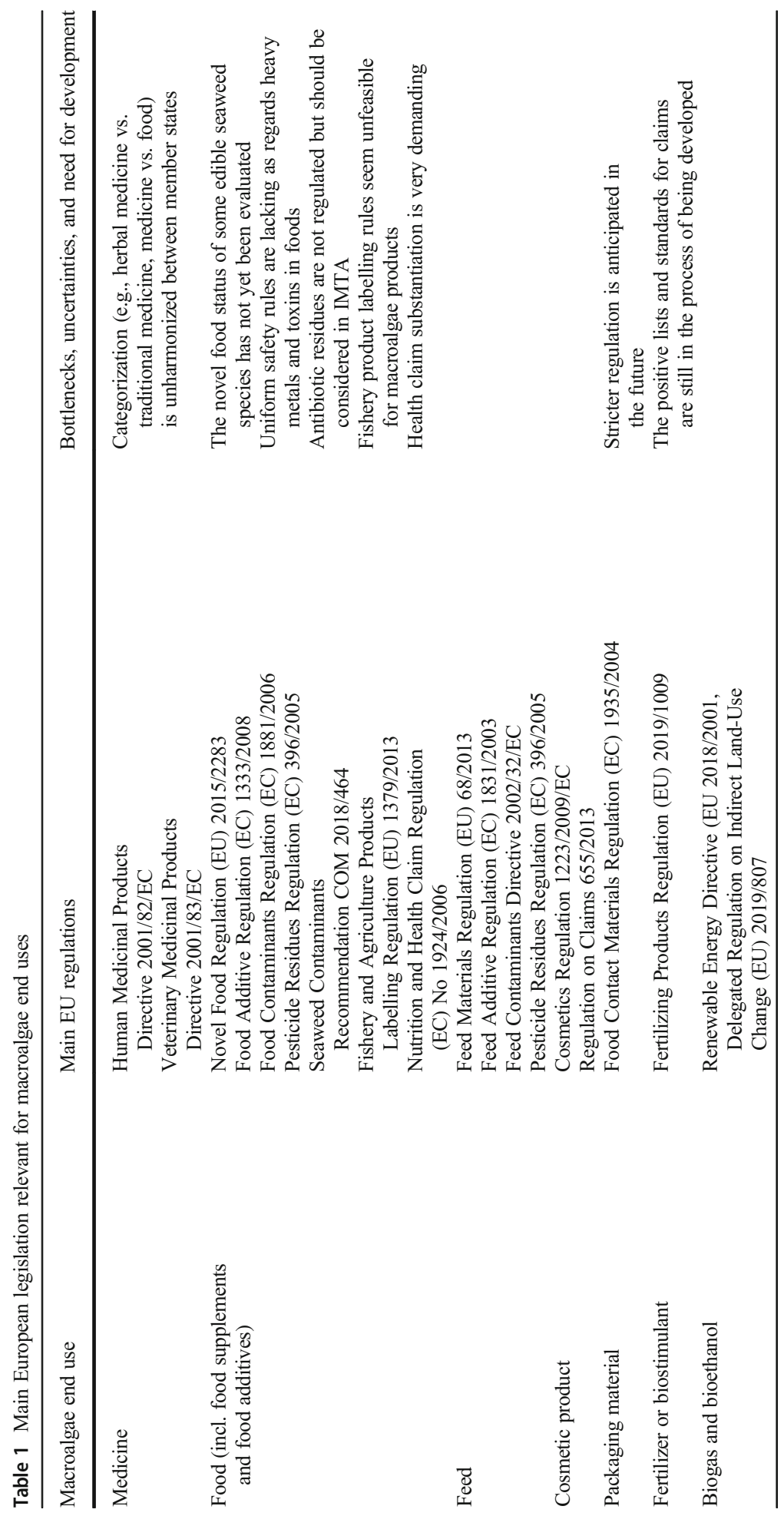


national laws, but concrete procurement criteria are decided at the level of individual procurement units.

- Tax schemes that add weight to environmental criteria benefit sustainable products. The EU sets the amount of possible VAT rate categories (a member state can have three), whereas tax rates are decided at member state level.

- $\quad$ Trade agreements between the EU and other countries or trade blocks may adopt criteria that favor sustainable products in the form of lower tariffs.

Funding Open access funding provided by Finnish Environment Institute (SYKE). This work was supported by the EU Interreg Baltic Sea Region program under the European Regional Development Fund.

\section{Compliance with ethical standards}

Conflict of interest The authors declare that they have no conflict of interest.

Ethical approval This article does not contain any studies with animals performed by any of the authors.

Open Access This article is licensed under a Creative Commons Attribution 4.0 International License, which permits use, sharing, adaptation, distribution and reproduction in any medium or format, as long as you give appropriate credit to the original author(s) and the source, provide a link to the Creative Commons licence, and indicate if changes were made. The images or other third party material in this article are included in the article's Creative Commons licence, unless indicated otherwise in a credit line to the material. If material is not included in the article's Creative Commons licence and your intended use is not permitted by statutory regulation or exceeds the permitted use, you will need to obtain permission directly from the copyright holder. To view a copy of this licence, visit http://creativecommons.org/licenses/by/4.0/.

\section{References}

Akila V, Arjunan M, Sahaya Suheektha D, Balakhrisnan S, Munusamy Ayyasamy P, Rajakumar S (2019) Biogas and biofertilizer production of marine macroalgae: an effective anaerobic digestion of Ulva sp. Biocatalysis and Agricultural Biotechnology 18:101035. https://doi.org/10.1016/j.bcab.2019.101035

Almela C, Jesus Clemente M, Velez D, Montoro R (2006) Total arsenic, inorganic arsenic, lead and cadmium contents in edible seaweed sold in Spain. Food Chem Toxicol 44(11):1901-1908

Ariede MB, Candido TM, Jacome ALM, Velasco MVR, de Carvalho JCM, Baby AR (2017) Cosmetic attributes of algae - a review. Algal Res 25:483-487

Aryee A, Agyei D, Akanbi T (2018) Recovery and utilization of seaweed pigments in food processing. Current Opinion in Food Science 19:113-119. https://doi.org/10.1016/j.cofs.2018.03.013

Bach D, Newman AL (2010) Governing lipitor and lipstick: capacity, sequencing and power in international pharmaceutical and cosmetics regulation. Rev Int Polit Econ 17(4):665-695

Bach SJ, Wang Y, McAllister TA (2008) Effect of feeding sun-dried seaweed (Ascophyllum nodosum) on fecal shedding of Escherichia coli O157:H7 by feedlot cattle and on growth performance of lambs. Anim Feed Sci Technol 142(1):17-32

Balina K, Romagnoli F, Blumberga D (2017) Seaweed biorefinery concept for sustainable use of marine resources. Energy Procedia 128:504-511

Barbier M, Charrier B, Araujo R, Holdt S, Jacquemin B, Rebours C (2019) PEGASUS - PHYCOMORPH European guidelines for a sustainable aquaculture of seaweeds, COST action FA1406 (M. Barbier and B. Charrier, Eds), Roscoff, France

Beaulieu L (2019) Insights into the regulation of algal proteins and bioactive peptides using proteomic and transcriptomic approaches. Molecules 24(9):1708

Bedoux G, Hardouin K, Burlot AS, Bourgougnon N (2014) Bioactive components from seaweeds: cosmetic applications and future development. Adv Bot Res 71:345-378 
Biancarosa I, Espe M, Bruckner CG, Heesch S, Liland N, Waagbø R, Torstensen B, Lock EJ (2017) Amino acid composition, protein content, and nitrogen-to-protein conversion factors of 21 seaweed species from Norwegian waters. J Appl Phycol 29:1001-1009. https://doi.org/10.1007/s10811-016-0984-3

Boney AD (1965) Aspects of the biology of the seaweeds of economic importance. Adv Mar Biol 3:105-253. https://doi.org/10.1016/S0065-2881(08)60397-1

Booth E (1969) The manufacture and properties of liquid seaweed extracts. Proceedings of International Seaweed Symposium 6:655-662

Bučas M, Daunys D, Olenin S (2007) Overgrowth patterns of the red algae Furcellaria lumbricalis at an exposed Baltic Sea coast: the results of a remote underwater video data analysis. Estuar Coast Shelf Sci 75(3):308316

Catarino M, Silva A, Cordoso S (2017) Fucaceae: a source of bioactive Phlorotannins. Int J Mol Sci 18(6):1327

Catarino M, Silva A, Mateus N, Cordoso M (2019) Optimization of phlorotannins extraction from Fucus vesiculosus and evaluation of their potential to prevent metabolic disorders. Marine Drugs 17(3):162

Cherry P, Yadav S, Strain C, Allsopp P, McSorley E, Ross R, Stanton C (2019) Prebiotics from seaweeds: an ocean of opportunity? Marine Dugs 17(6):327

Cole AJ, Roberts DA, Garside AL, deNys R, Paul NA (2016) Seaweed compost for agricultural crop production. J Appl Phycol 28:629-642

Couteau C, Coiffard L (2016) Seaweed applications in cosmetics. In: Fleurence J, Levine I (eds) Seaweed in health and disease prevention. Academic Press

de Jesus Raposo M, de Morais A, de Morais R (2016) Emergent sources of prebiotics: seaweeds and microalgae. Marine Drugs 14(2):27. https://doi.org/10.3390/md14020027

Diapharm company webpage (2020) https://www.diapharm.com/en/news/first-natural-herbal-medicine-foroverweight-patients-registered-in-germany-and-available-throughout-the-eu/). Accessed 20 July 2020

Dierick N, Ovyn A, De Smet S (2009) Effect of feeding intact brown seaweed Ascophyllum nodosum on some digestive parameters and on iodine content in edible tissues in pigs. Journal of the Science in Food and Agriculture 89:584-594. https://doi.org/10.1002/jsfa.3480

Dumay J, Morançais M, Munier M, Le Guillard C, Fleurence J (2014) Chapter 11. Phycoerythrins: valuable proteinic pigments in red seaweeds. In: Bourgougnon N (ed) Advances in botanical research - sea plants, vol 71. Elsevier, Amsterdam, pp 321-343

EBIC website (2012) http://www.biostimulants.eu/website. Accessed 14 December 2019

Edmonds JS, Francesconi KA (2003) Organoarsenic compounds in the marine environment. In: Craig PJ (ed) Organometallic compounds in the environment, 2nd edn. Wiley, Chichester, pp 195-222

Ergün S, Soyutürk M, Güroy B, Güroy D, Merrifield D (2009) Influence of Ulva meal on growth, feed utilization, and body composition of juvenile Nile tilapia (Oreochromis niloticus) at two levels of dietary lipid. Aquac Int 17:355-361

European Commission (2015) Clarification of the absence of European harmonised standard for natural and organic cosmetics. Available at: https:/ec.europa.eu/docsroom/documents/13179/attachments/1/ translations/. Accessed 14 August 2020

European Commission (2017) Food from the ocean. Scientific Opinion No. 3/2017 Publications Office of the European Union, Luxembourg. Available at: https://ec.europa.eu/research/sam/pdf/sam_food-from-oceans report.pdf. Accessed 14 August 2020

European Parliament News (2015) European Committee backs switchover to advanced biofuels. Press release Environment - 24-02-2015. Available at: http://www.europarl.europa.eu/news/en/news-room/content/ 20150223IPR24714/html/Environment-Committee-backs-switchover-to-advanced-biofuels. Accessed 14 August 2020

Fan X, Bai L, Liang B, Li Z, Zhang X (2014) Marine algae-derived bioactive peptides for human nutrition and health. J Agric Food Chem 62(38):9211-9222

FAO (2009) How to Feed the World in:2050 Available at: http://www.fao.org/fileadmin/templates/wsfs/docs/ expert_paper/How_to_Feed_the_World_in_2050.pdf

FAO (2018) Ferdouse, F., Lovstad Holdt, $\bar{S} ., \bar{S}$. production, trade and utilization. FAO Globefish Research Programme Vol. 124. Available at: http://www. fao.org/in-action/globefish/publications/details-publication/en/c/1154074/

FAO (2019) Online query panels for aquaculture and capture production of seaweeds. Both accessed 13 August 2020. http://www.fao.org/fishery/statistics/global-aquaculture-production/query/en http://www.fao.org/ fishery/statistics/global-capture-production/query/en

Featonby-Smith BC, van Staden J (1984) The effect of seaweed concentrate and fertilizer on growth and the endogenous cytokinin content of Phaseolus vulgaris. S Afr J Bot 3(6):375-379

Forskrift om høsting av tare, Møre og Romsdal og Trøndelag (2019) FOR-2019-09-26-1274. 26th September 2019. [Regulation on seaweed harvesting, Møre and Romsdal and Trøndelag). https://lovdata.no/dokument/ LTII/forskrift/2019-09-26-1274 
Franzén D, Infantes E, Gröndahl F (2019) Beach-cast as biofertiliser in the Baltic Sea region - potential limitations due to cadmium-content. Ocean \& Coastal Management 169:20-26. https://doi.org/10.1016/j. ocecoaman.2018.11.015

Freitas AC, Rodrigues D, Rocha-Santos TAP, Gomes AMP, Duarte AC (2012) Marine biotechnology advances towards applications in new functional foods. Biotechnol Adv 30(6):1506-1515

Ganesan AR, Shanmugam M, Bhat R (2018) Producing novel edible films from semi refined carrageenan (SRC) and ulvan polysaccharides for potential food applications. Int J Biol Macromol 112:1164-1170

Garcia-Vaquero M, Hayes M (2016) Red and green macroalgae for fish, animal feed and human functional food development. Food Reviews International 32(1):15-45. https://doi.org/10.1080/87559129.2015.1041184

Greger M, Malm T, Kautsky L (2007) Heavy metal transfer from composted macroalgae to crops. European Journal of Agronomy 26(3):257-265

Gubelit Y, Makhutova O, Sushchik N, Kolmakova A, Kalachova G, Gladyshev M (2015) Fatty acid and elemental composition of littoral "green tide" algae from the Gulf of Finland, the Baltic Sea. J Appl Phycol 27:375-386

Guidara M, Yaich H, Richel A, Blecker C, Boufi S, Attia H, Garna H (2019) Effects of extraction procedures and plasticizer concentration on the optical, thermal, structural and antioxidant properties of novel ulvan films. International Journal of Biological Macromolecules 135:647-658

Güroy BK, Cirik Ș, Güroy D, Sanver F, Tekinay AA (2009) Effects of Ulva rigida and Cystoseira barbata meals as a feed additive on growth performance, feed utilization, and body composition of Nile tilapia, Oreochromis niloticus. Turkish Journal of Veterinary Animal Science 31(2):91-97

Holdt S, Kraan S (2011) Bioactive compounds in seaweed: functional food applications and legislation. J Appl Phycol 23:543-597

Ibañez E, Cifuentes A (2013) Benefits of using algae as natural sources of functional ingredients. J Sci Food Agric 93(4):703-709. https://doi.org/10.1002/jsfa.6023

Jacob A, Xia A, Gunning D, Burnell G, Murphy JD (2016) Seaweed biofuel derived from integrated multitrophic aquaculture. International Journal of Environmental Science and Development 7(11):805-809

Jacobsen C, Sørensen AD, Holdt S, Akoh C, Hermund D (2019) Source, extraction, characterization, and applications of novel antioxidants from seaweed. Annu Rev Food Sci Technol 10:541-568. https://doi.org/ 10.1146/annurev-food-032818-121401

Jard G, Marfaing H, Carrère H, Delgenes JP, Steyer JP, Dumas C (2013) French Brittany macroalgae screening: composition and methane potential for potential alternative sources of energy and products. Bioresour Technol 144:492-498

Jones JM, Dawes CP (1987) Useful European seaweeds: past hopes and present cultivation. Hydrobiologia 1511152: 173-181. M. A. Ragan and C. J. Bird (eds) Twelfth International Seaweed Symposium

Joshi A, Desai AY, Mulye V (2015) Seaweed resources and utilization: an overview. Biotech Express 2(22)

Joshi, S., Kumari, R. \& Upasani, V.N. (2018) Applications of algae in cosmetics: an overview. International Journal of Innovative Research in Science, Engineering and Technology, 7(2)

Karatzia M, Christaki E, Bonos E, Karatzias C, Florou-Paneri P (2012) The influence of dietary Ascophyllum nodosum on haematologic parameters of dairy cows. Ital J Anim Sci 11(2):e31

Khan W, Rayorath UP, Subramanian S et al (2009) Seaweed extracts as biostimulants of plant growth and development. J Plant Growth Regul 28:386-399

Lahaye M, Robic A (2007) Structure and function properties of Ulvan, a polysaccharide from green seaweeds. Biomacromolecules 8(6):1765-1774

Lakshmi S, Sankaranarayanan S, Galaria T et al (2020) A short review on the valorization of green seaweeds and Ulvan: FEEDSTOCK for chemicals and biomaterials. Biomolecules 10(7):991

Lüning K, Pang S (2003) Mass cultivation of seaweeds: current aspects and approaches. J Appl Phycol 15:115119

Mac Monagail M, Cornish L, Morrison L, Araújo R, Critchley AT (2017) Sustainable harvesting of wild seaweed resources. Eur J Phycol 52(4):371-390. https://doi.org/10.1080/09670262.2017.1365273

MacArtain P, Gill CIR, Brooks M, Campbell R, Rowland IR (2007) Nutritional value of edible seaweeds. Nutr Rev 65:535-543

Maia M, Fonseca A, Oliveira H, Mendonç C, Cabrita A (2016) The potential role of seaweeds in the natural manipulation of rumen fermentation and methane production. Nat Sci Rep 6:32321

McCandless EL (1981) Polysaccharides of the seaweeds. In The Biology of Seaweeds, Eds. C S Lobban and M J Wynne. pp 559-588. Univ. Calif. Press, Berkeley.

Mesquita Marques M (2017) From macroalgae to bioplastic. Seaweed Hydrolysis for Polyhydroxyalkanoate Production by Marine Bacteria. Masters' thesis

Muncke J, Backhaus T, Geueke B, Maffini MV, Martin OV, Myers JP, Soto AM, Trasande L, Trier X, Scheringer M (2017) Scientific challenges in the risk assessment of food contact materials. Environ Health Perspect 125(9):095001 
Muncke J, Andersson A, Backhaus T et al (2020) Impacts of food contact chemicals on human health: a consensus statement. Environ Health 19:25

Murphy JD, Drosg B, Allen E, Jerney J, Xia A, Herrmann C (2015) A perspective on algal biogas. IEA Bioenergy. Available at https:/www.ieabioenergy.com/wp-content/uploads/2015/09/AD_of_Algae_ebook_ end.pdf. Accessed 14 August 2020

Mustafa G, Wakamatsu S, Takeda T-A, Umino T, Nakagawa H (1995) Effects of algae meal as feed additive on growth, feed efficiency, and body composition in red sea bream. Fish Sci 61(1):25-28

Nielsen HB, Heiske S (2011) Anaerobic digestion of macroalgae: methane potentials, pre-treatment, inhibition and co-digestion. Water Sci Technol 64(8):1723-1729

Nohynek, G.J., Antignac, E. \& Toutain (2010) Safety assessment of personal care products/cosmetics and their ingredients. Toxicol Appl Pharmacol, 243(2), 239-259. https://doi.org/10.1016/j.taap.2009.12.001

PackagingEurope.com (2019) Packaging from the sea, 5 July 2019 Available at: https://packagingeuropecom/ creating-packaging-from-algae/ Visited 13 August 2020

Pimentel FB, Alves RC, Rodrigues F, Beatriz M, Oliveira P (2018) Macroalgae-derived ingredients for cosmetic industry - an update. Cosmetics 5(1):2. https://doi.org/10.3390/cosmetics5010002

Rebours C, Marinho-Soriano E, Zertuche-González JA, Hayashi L, Vásquez JA, Kradolfer P, Soriano G, Ugarte R, Abreu MH, Bay-Larsen I, Hovelsrud G, Rødven R, Robledo D (2014) Seaweeds: an opportunity for wealth and sustainable livelihood for coastal communities. J Appl Phycol 26:1939-1951. https://doi.org/10. 1007/s10811-014-0304-8

Rey-Crespo F, Lopez-Alonso M, Miranda M (2014) The use of seaweed from the Galician coast as a mineral supplement in organic dairy cattle. Animal 8(4):580-586

Ricci M, Tilbury L, Daridon B, Sukalac K (2019) General principles to justify plant biostimulant claims. Frontiers of Plant Science 10:494

Roesijadi G, Jones SB, Snowden-Swan LJ, Zhu Y (2010) Macroalgae as a biomass feedstock: a preliminary analysis United States Department of Energy Pacific Northwest National Laboratory. PNNL:19944

Rosa J, Lemos MFL, Crespo D, Nunes M, Freitas A, Ramos F, Pardal MÂ, \& Leston S (2020) Integrated multitrophic aquaculture systems - Potential risks for food safety. Trends Food Sci Technol 96:79-90

Rust MB, Barrows FT, Hardy RW, Lazur A, Naughten K, Silverstein J (2011) The future of aquafeeds. NOAA/ USDA Alternative Feeds Initiative, Silver Spring, MD

Saratale RG, Kumar G, Banu R, Xia A, Periyasamy S, Saratale GD (2018) A critical review on anaerobic digestion of microalgae and macroalgae and co-digestion of biomass for enhanced methane generation. Bioresour Technol 262:319-332

Schiel DR, Foster MS (2015) The biology and ecology of giant kelp forests. University of California Press

Sharma S, Fleming C, Selby C, Rao J, Martin T (2014) Plant biostimulants: a review on the processing of macroalgae and use of extracts for crop management to reduce abiotic and biotic stresses. J Appl Phycol 26:465-490

Simoneau C, Raffael B, Garbin S, Hoekstra E, Mieth A, Alberto Lopes JF, et al, (2016) Non-harmonised food contact materials in the EU: regulatory and market situation: BASELINE STUDY: final report. Available: https://publications.jrc.ec.europa.eu/repository/handle/JRC104198. Accessed 13 March 2020

Skjermo J, Aasen IM, Arff J et al (2014) A new Norwegian bioeconomy based on cultivation and processing of seaweeds: opportunities and R\&D needs. SINTEF Fisheries and Aquaculture - Report A25981. Available at: https:/www.sintef.no/contentassets/04aa6cd738b245979b334715163c0506/seaweed-bioeconomy-2014revised-2.pdf. Accessed 13 August 2020

Solrød Kommune (2014). Solrød Biogas - conception, project development and realization Written and published by Solrød Kommune Teknik og Miljø Solrød Center 12680 Solrød Strand

Stirk WA, Novak MS, van Staden J (2003) Cytokinins in macroalgae. Plant Growth Regul 41(1):13-24

Suutari M, Leskinen E, Spilling K, Kostamo K, Seppälä J (2017) Nutrient removal by biomass accumulation on artificial substrata in the northern Baltic Sea. J Appl Phycol 29:1707-1720

Svendsen P (1972) Noen observasjoner over taretråling og gjenvekst av stortare, Laminaria hyperborea. [Some observations on kelp trawling and regrowth of Laminaria hyperborea]. Fiskets Gang 22:448-460 [In Norwegian with English summary]

Swedish-EPA (2013) Hållbar Återföring Av Fosfor (sustainable phosphorous recycling, in Swedish with English summary), report 6580. Stockholm, Sweden

Tabarsa M, Rezaei M, Ramezanpour Z, Waaland JR (2012) Chemical compositions of the marine algae Gracilaria Salicornia (Rhodophyta) and Ulva lactuca (Chlorophyta) as a potential food source. Journal of Science in Food and Agriculture 92(12):2500-2506

Tedesco S, Barroso TM, Olabi AG (2014) Optimization of mechanical pre-treatment of Laminariaceae spp. biomass-derived biogas. Renew Energy 62:527-534

Temple WD, Bomke AA (1988) Effects of kelp (Macrocystis integrifolia) on soil chemical properties and crop responses. Plant Soil 105:213-222. https://doi.org/10.1007/BF02206260

Torres MD, Kraan S, Domínguez H (2019) Seaweed biorefinery. Rev Environ Sci Biotechnol 18(2):335-388 
Tziveleka L-A, Pippa N, Georgantea P, Ioannou E, Demetzos C, Roussis V (2018) Marine sulfated polysaccharides as versatile polyelectrolytes for the development of drug delivery nanoplatforms: complexation of ulvan with lysozyme. Int J Biol Macromol 118:69-75

Valente LMP, Gouveia A, Rema P, Matos J, Gomes EF, Pinto IS (2006) Evaluation of three seaweeds Gracilaria bursa-pastoris, Ulva rigida and Gracilaria cornea as dietary ingredients in European sea bass (Dicentrarchus labrax) juveniles. Aquaculture 252:85-91

van Loon LC, van Strien EA (1999) The families of pathogenes is related proteins, their activities, and comparative analysis of PR1 type proteins. Physiol Mol Plant Pathol 55(2):85-97

Vásquez JA, Piaget N, Vega JMA (2012) The Lessonia nigrescens fishery in northern Chile: how you harvest is more important than how much you harvest. J Appl Phycol 24:417-426

Vea J, Ask E (2011) Creating a sustainable commercial harvest of Laminaria hyperborea, in Norway. J Appl Phycol 23:489-494. https://doi.org/10.1007/s10811-010-9610-y

Vera J, Castro J, Gonzalez A, Moenne A (2011) Seaweed polysaccharides and derived oligosaccharides stimulate defense responses and protection against pathogens in plants. Marine Drugs 9:2514-2525

Verdy C, Branka JE, Mekideche N (2011) Quantitative assessment of lactate and progerin production in normal human cutaneous cells during normal ageing: effect of an Alaria esculenta extract. International Journal of Cosmetics Science 33(5):462-466

Wan AHL, Davies SJ, Soler-Vila A, Fitzgerald R, Johnson MP (2018) Macroalgae as a sustainable aquafeed ingredient. Rev Aquac 11(3):458-492

Wang H-M, Chen C-C, Huynh P, Chang J-S (2015) Exploring the potential of using algae in cosmetics. Bioresour Technol 184:255-362

Wassef EA, El-Sayed A-FM, Sakr EM (2013) Pterocladia (Rhodophyta) and Ulva (Chlorophyta) as feed supplements for European seabass, Dicentrarchus labrax L., fry. Journal of Applied Phycology 25:1369-1376

Wosnitza TMA, Barrantes JG (2006) Utilization of seaweed Ulva sp.in paracas bay (Peru): experimenting with compost. Journal of Applied Phycology 18:27

Zakaria Z (2015) Regulation of cosmetics: what has Malaysia learnt from the European system? J Consum Policy 38:39-59

Zappelli C, Barbulova A, Apone F, Colucci G (2016) Effective active ingredients obtained through biotechnology. Cosmetics 3:39

Zemke-White WL, Ahno M (1999) World seaweed utilization: an end-of-century summary. J Appl Phycol 11:369-376

Zhang X (1997) Influence of plant growth regulators on turfgrass growth, antioxidant status, and drought tolerance. PhD thesis, Virginia Polytechnic Institute and State University, Blacksburg, Virginia

Zhang Z, Wang F, Wang X, Liu X, Hou Y, Zhang Q (2010) Extraction of the polysaccharides from five algae and their potential antioxidant activity in vitro. Carbohydr Polym 82:118-121

Zodape ST (2001) Seaweeds as a biofertilizer. J Sci Ind Res 60:378-382

Publisher's note Springer Nature remains neutral with regard to jurisdictional claims in published maps and institutional affiliations. 


\title{
Affiliations
}

\section{Anu Lähteenmäki-Uutela ${ }^{1} \cdot$ Moona Rahikainen $^{2}$ • María Teresa Camarena-Gómez ${ }^{3}$.

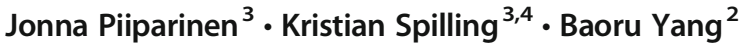

\author{
Moona Rahikainen \\ moona.rahikainen@utu.fi \\ María Teresa Camarena-Gómez \\ teresa.camarenagomez@ymparisto.fi \\ Jonna Piiparinen \\ jonna.piiparinen@ymparisto.fi
}

Kristian Spilling

kristian.spilling@ymparisto.fi

Baoru Yang

baoru.yang@utu.fi

1 Environmental Policy Centre, Finnish Environment Institute, Latokartanonkaari 11, 00790 Helsinki, Finland

2 Food Chemistry and Food Development, Department of Biochemistry, University of Turku, Itäinen Pitkäkatu 4, 20520 Turku, Finland

3 Marine Research Centre, Finnish Environment Institute, Latokartanonkaari 11, 00790 Helsinki, Finland

4 Department of Natural Sciences, University of Agder, Kristiansand, Norway 